\title{
ACIDIC AND NEUTRAL LIQUID INGESTION IN PATIENTS WITH GASTROESOPHAGEAL REFLUX DISEASE
}

\author{
Dafne Calsoni GOMES and Roberto Oliveira DANTAS
}

\begin{abstract}
Context - Sour acidic liquid has a slower distal esophageal transit than a neutral liquid. Our hypothesis was that an acidic sour bolus has a different ingestion dynamic than a neutral bolus. Method - In 50 healthy volunteers and 29 patients with gastroesophageal reflux disease (GERD), we evaluated the ingestion dynamics of $100 \mathrm{~mL}$ of acidic sour liquid (concentrated lemon juice, $\mathrm{pH}: 3.0$ ) and $100 \mathrm{~mL}$ of water (pH: 6.8). The time to ingest the total volume, the number of swallows to ingest the volume, the interval between swallows, the flux of ingestion and the volume ingested in each swallow was measured. Results - In both groups, healthy volunteers and patients in treatment for GERD, the acidic liquid took longer to be ingested, a higher number of swallows, a slower flux of ingestion and a smaller volume in each swallow than the neutral bolus. There was no difference between healthy volunteers and patients with GERD. The ingestion in women was longer than in men for acidic and neutral liquids. Conclusion Acidic liquid has a different dynamic of ingestion than the neutral liquid, which may be consequence of the slower transit through the distal esophageal body or an anticipation to drink a sour bolus. Patients with GERD have the same prolonged ingestion of the acidic liquid bolus as seen in healthy volunteers.
\end{abstract}

HEADINGS - Gastroesophageal reflux. Deglutition disorders. Acidity.

\section{INTRODUCTION}

The control of swallowing involves a complex interaction between muscles and nerves that coordinates the safe passage of swallowed material from the mouth to the stomach ${ }^{(13)}$. It is an ongoing process that involves the mouth, pharynx and esophagus, many oral structures, muscles and nerves.

The process of swallowing can be altered by diseases such as gastroesophageal reflux disease (GERD) ${ }^{(8)}$, which is characterized by the return of food contents present in the stomach into the esophagus, causing symptoms and impairing the quality of life of patients $^{(18)}$. The refluxed material generally has an acid $\mathrm{pH}$, with the presence of hydrochloric acid and pepsin and at times bile acids and pancreatic enzymes that can irritate and damage the lining of the esophagus and cause symptoms and alter sensitivity ${ }^{(6)}$. Hypersensitivity to acid may occur in patients with erosive and non erosive GERD ${ }^{(7)}$.

GERD is the most common identifiable cause of dysphagia ${ }^{(15)}$. In GERD, changes occur in the oropharyngeal transit of liquids and soft foods, being slower in these patients compared to the transit time in healthy subjects ${ }^{(8)}$. Patients with GERD have impairment of esophageal chemical clearance ${ }^{(12)}$ and erosive esophagitis causes longer esophageal bolus transit ${ }^{(10)}$. In the esophagus of healthy individuals and in patients who have suffered stroke, it was observed that a bolus with a sour taste and acidic $\mathrm{pH}$ has slower transit in the distal part when compared with a bolus with neutral $\mathrm{pH}^{(3,4)}$. Thus, it may be that the flavor and/or $\mathrm{pH}$ of the swallowed liquid have influence on the swallowing of patients with GERD.

Women have less ingestion flow and volume in each swallow than men ${ }^{(2)}$, probably due to the adaptation to anatomical differences and a lower oral volume capacity ${ }^{(16)}$, which can be influenced by taste and $\mathrm{pH}$.

Our hypothesis is that the ingestion of a sour liquid with acidic $\mathrm{pH}$ has a different ingestion dynamic than the ingestion of a liquid with neutral taste and $\mathrm{pH}$; with GERD patients, the ingestion of a sour liquid with acidic $\mathrm{pH}$ would take longer that in healthy subjects. Our aim in this investigation was to evaluate this ingestion in patients with GERD and individuals without the disease, and to verify the effect of gender.

\section{METHODS}

Seventy-nine individuals of both sexes were enrolled in the study. Twenty-nine subjects had a diagnosis of GERD, characterized by symptoms (heartburn and regurgitation) and diagnosed by upper GI endoscopy with esophagitis grade A or B of the 
Los Angeles classification ( $\mathrm{n}=17$ ) and/or abnormal 24-hour intraesophageal $\mathrm{pH}$ monitoring $(\mathrm{n}=15)^{(7,18)}$. All subjects were in treatment of the disease with proton pump inhibitors, with symptom control. There were 21 women and 8 men, aged 21-78 years (mean: $50.5 \pm 12.8$ years). The control group consisted of 50 subjects, 34 women and 16 men, aged 18-73 years (mean: $36.4 \pm 16.2$ years). To evaluate the effect of gender, two groups were formed between men $(n=24)$ and women $(n=55)$. The components of the two groups had no neurological or endocrine diseases, difficulty with swallowing or malnutrition. The control subjects had no gastrointestinal complaints. Patients were recruited from the outpatient medical and surgical clinics of the Hospital das Clínicas, Ribeirão Preto (HCRP). Control subjects were recruited from among the companions of the patients and those that work and study within the hospital of the institution. The research protocol was approved by the research Ethics Committee of both the HCRP and the Ribeirão Preto Medical School - University of São Paulo (FMRP-USP). Written informed consent was obtained from all participants.

The test was performed by ingestion, at room temperature, in duplicate, of $100 \mathrm{~mL}$ of water (pH 6.8) and $100 \mathrm{~mL}$ of lemon juice ( $\mathrm{pH} 3.0$ ) prepared with $12 \mathrm{~g}$ of powdered juice (Fit Diet, Ajinomoto Inter Ind. e Com Ltda, Limeira SP) diluted in $200 \mathrm{~mL}$ of water. Ingestion was continuous and comfortable to the individual, with simultaneous measurements of the time of ingestion, measured by stopwatch, and the number of swallows necessary for the ingestion of the entire volume. The alternating sequence of ingestion was drawn beforehand between two options: one starting with water and the other lemon.

The tests were performed with the subject sitting with the head in a neutral position, looking straight ahead. The liquids were offered in disposable plastic cups with a capacity of $100 \mathrm{~mL}$. The interval between tests was a minimum time of 1 minute. Ingestion started when the liquid touched the lips of the subject and ended when the thyroid cartilage returned to resting position after the last swallow.

With the values of ingestion time and the number of swallows, we calculate: (1) interval between swallows - the total time of ingestion divided by the number of swallows; (2) ingestion flow - the total volume ingested $(100 \mathrm{~mL})$ divided by the time of ingestion; (3) swallowing volume - the total volume ingested $(100 \mathrm{~mL})$ divided by the number of swallows $^{(1,9,13,14)}$.

For statistical evaluation, a linear regression model was used with mixed effects (random and fixed effects). Linear mixed models are used in data analysis in which responses are grouped (more than one measure for an individual) and the assumption of independence between observations in the same group is not adequate ${ }^{(2)}$. These models have the assumption that their waste has normal distribution with mean 0 and variance $\sigma^{2}$. In situations where this assumption was not observed, a logarithmic transformation was used in the response variable. This procedure was performed using the $\mathrm{SAS}^{\circledR} 9.0$ software, using PROC MIXED. The results are presented in mean and $95 \%$ confidence interval $(95 \% \mathrm{CI})$.

\section{RESULTS}

In both the healthy subjects forming the control group (Table 1) and the patients with GERD (Table 2), the acidic liquid took longer to be ingested, with a greater number of swallows, slower ingestion flow and lower volume in each swallow compared with the neutral fluid $(P<0.01)$. There was no difference between the control subjects and patients with GERD $(P>0.20)$ in time to ingest the entire volume, the number of swallows, the interval between swallows, the ingestion flow (Figure 1) and the volume in each swallow (Figure 2).

TABLE 1. Ingestion of $100 \mathrm{~mL}$ of water and $100 \mathrm{~mL}$ of lemon juice in normal subjects $(\mathrm{n}=50)$

\begin{tabular}{lccccc}
\hline & \multicolumn{2}{c}{ Water } & \multicolumn{2}{c}{ Lemon } & \\
& Mean & $95 \%$ CI & Mean & $95 \%$ CI & $P$ value \\
\hline Time (s) & 8.1 & $7.5-8.8$ & 9.9 & $8.9-11.0$ & $<0.01$ \\
Number & 6.3 & $5.9-6.7$ & 7.4 & $6.8-8.0$ & $<0.01$ \\
Interval (s) & 1.3 & $1.2-1.4$ & 1.3 & $1.3-1.4$ & 0.53 \\
& & $13.1-$ & & $11.5-$ & \\
Flow (mL/s) & 14.2 & 15.3 & 12.7 & 13.8 & $<0.01$ \\
& & $16.4-$ & & $14.3-$ & \\
Volume (mL) & 17.6 & 18.8 & 15.4 & 16.4 & $<0.01$ \\
\hline
\end{tabular}

CI: confidence interval

TABLE 2. Ingestion of $100 \mathrm{~mL}$ of water and $100 \mathrm{~mL}$ of lemon juice in patients with gastroesophageal reflux disease $(n=29)$.

\begin{tabular}{lccccc}
\hline & \multicolumn{2}{c}{ Water } & \multicolumn{2}{c}{ Lemon } & \\
& MEAN & $95 \%$ CI & MEAN & $95 \%$ CI & $\boldsymbol{P}$ value \\
\hline Time (s) & 9.3 & $8.2-10.5$ & 11.3 & $9.9-12.6$ & $<0.01$ \\
Number & 6.7 & $6.0-7.7$ & 7.7 & $7.1-8.4$ & $<0.01$ \\
Interval (s) & 1.4 & $1.3-1.5$ & 1.4 & $1.3-1.5$ & 0.50 \\
Flow (mL/s) & 12.7 & $11.4-14.0$ & 10.6 & $9.6-11.6$ & $<0.01$ \\
Volume (mL) & 16.7 & $15.3-18.1$ & 14.2 & $13.1-15.3$ & $<0.01$ \\
\hline
\end{tabular}

CI: confidence interval

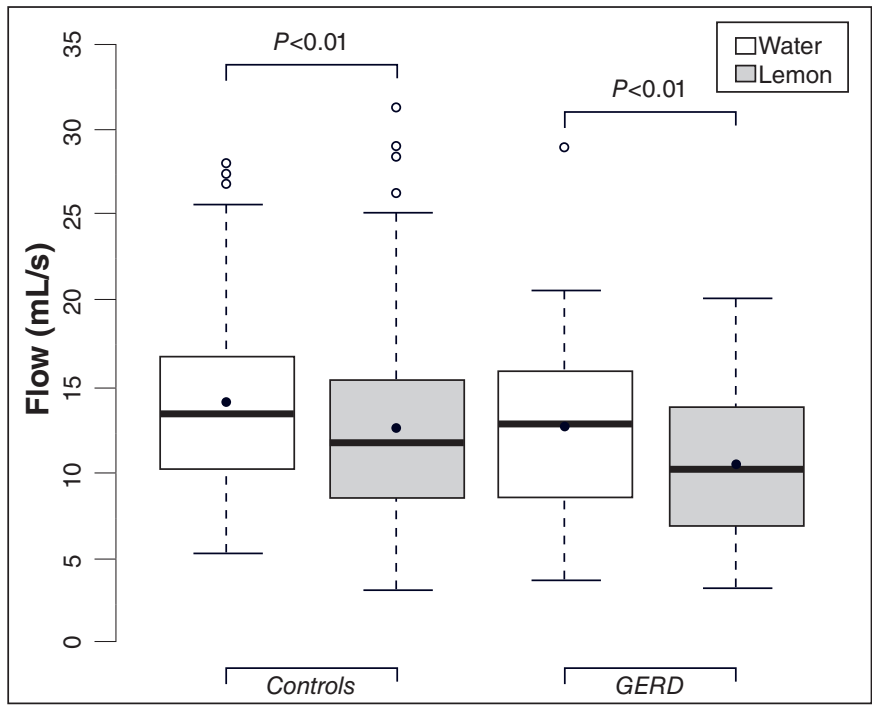

FIGURE 1. Box plot of ingestion flow of $100 \mathrm{~mL}$ of water and $100 \mathrm{~mL}$ of concentrated lemon juice in healthy subjects $(n=50)$ and patients with gastroesophageal reflux disease $(\mathrm{GERD}, \mathrm{n}=29)$. 


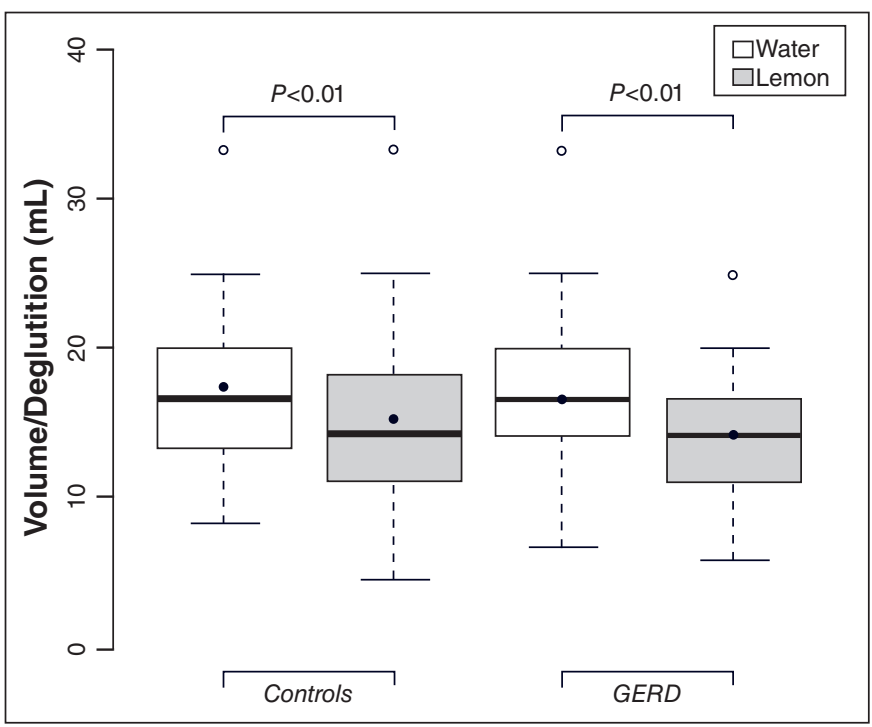

FIGURE 2. Box plot of volume of each swallow with ingestion of $100 \mathrm{~mL}$ of water and $100 \mathrm{~mL}$ of concentrated lemon juice in healthy subjects $(\mathrm{n}=50)$ and patients with gastroesophageal reflux disease (GERD, $\mathrm{n}=29)$.

Analyzing all subjects studied $(\mathrm{n}=79)$, we observed that women had the longest ingestion time, greater number of swallows, smaller ingestion flow and volume in each swallow than men (Table 3, $P<0.01$ ). sour bolus than a neutral bolus ${ }^{(17)}$. This might cause modifications of oral and pharyngeal phases of swallowing, but there is no difference between acidic or neutral bolus in the oral and pharyngeal transits ${ }^{(4)}$. In normal subjects the swallowing function should work at its best, without significant influence of the bolus taste ${ }^{(4,5)}$.

The observed difference in ingestion may be related with the esophageal phase of swallowing. Alterations in esophagus may also cause alterations in pharyngeal function ${ }^{(22)}$. In proximal esophagus, the transit of an acidic bolus is faster than a neutral bolus, which should be consequence of the stronger contraction of muscles ${ }^{(17)}$, and in middle and in distal esophagus, the transit is slower, associated with an increase of the amount of distal esophageal residues ${ }^{(4)}$. Ineffective esophageal motility, present in some patients with GERD ${ }^{(18)}$, should have influence on the esophageal transit, but the same influence should be seen with the neutral bolus. Ineffective esophageal motility has little effect on esophageal acidic clearance in upright position $^{(21)}$.

The results might be different if the patients were not in treatment. Control of the symptoms (heartburn and regurgitation) might cause no further response to the ingestion of the acidic liquid. We expected that the ingestion of an acidic bolus by patients with GERD would be different from normal volunteers, but there was no difference, indicating the possibility that the disease does not cause alteration of liquid ingestion.

TABLE 3. Ingestion of $100 \mathrm{~mL}$ of water and $100 \mathrm{~mL}$ of lemon juice in men $(\mathrm{n}=24)$ and women $(\mathrm{n}=55)$.

\begin{tabular}{lcccccccccc}
\hline & \multicolumn{3}{c}{ Men } & \multicolumn{3}{c}{ Water } & \multicolumn{3}{c}{ Lemon } \\
& Mean & $95 \%$ CI & Mean & $95 \%$ CI & P value & Mean & 95\% CI & Mean & $95 \%$ CI & $\boldsymbol{P}$ value \\
\hline Time (s) & 7.0 & $6.0-7.9$ & 9.3 & $8.6-10.0$ & $<0.01$ & 7.8 & $6.8-8.7$ & 11.6 & $10.6-12.6$ & $<0.01$ \\
Number & 5.7 & $5.1-6.2$ & 6.8 & $6.4-7.1$ & $<0.01$ & 6.3 & $5.7-6.9$ & 8.1 & $7.5-8.6$ & $<0.01$ \\
Interval (s) & 1.2 & $1.2-1.3$ & 1.4 & $1.3-1.5$ & 0.11 & 1.2 & $1.1-1.3$ & 1.4 & $1.3-1.5$ & 0.02 \\
Flow (mL/s) & 16.6 & $15.0-18.3$ & 12.3 & $11.5-13.2$ & $<0.01$ & 15.2 & $13.4-17.0$ & 10.4 & $9.7-11.2$ & $<0.01$ \\
Volume (mL) & 19.7 & $17.8-21.7$ & 16.2 & $15.3-17.1$ & $<0.01$ & 17.7 & $16.0-19.4$ & 13.7 & $12.9-14.5$ & $<0.01$ \\
\hline
\end{tabular}

CI: confidence interval

\section{DISCUSSION}

This study aimed to analyze the intake of acidic and neutral liquids in healthy subjects and patients with GERD. This was performed with the swallowing of liquid test, which is considered a reliable method for measuring the performance of swallowing ${ }^{(1,9,13,14)}$. From the data obtained, we observed that the ingestion of sour liquid with acid $\mathrm{pH}$ is prolonged in relation to the ingestion of no flavored liquid and neutral $\mathrm{pH}$.

Previous investigation showed that the acidity of the bolus does not induce differences in the durations of the oral and pharyngeal phases of swallowing, nor in the residues amounts remaining in the mouth and pharyn $\mathrm{x}^{(4)}$. Electromyographic activity of the mylohyoid, geniohyoid and anterior belly of the digastric muscles is stronger with swallows of a
The longer esophageal distal clearance of the acidic bolus, seen in healthy subjects and patients with stroke ${ }^{(3,4)}$, may have influence on the pharyngeal phase of swallowing, an involuntary phase which may have adaptations to the slower esophageal transit, as is seen in Chagas' disease ${ }^{(19)}$. Another possibility is that the slower swallowing is a behavior to avoid a fast alteration of intra-esophageal $\mathrm{pH}$. In normal situations, the intraesophageal $\mathrm{pH}$ is near seven. Gastroesophageal reflux causes a fall in the intraesophageal $\mathrm{pH}$, with primary or secondary contractions (volume clearance) and the acid neutralization by saliva (chemical clearance), restoring the $\mathrm{pH}$ to normal values.

The mixed sensory stimuli (olfactory, visual and taste) are another alternative for explanation of a longer ingestion of the acidic bolus. The sour bolus is considered by the population as an unpleasant bolus taste ${ }^{(4,5)}$, which 
can have influence in the anticipation of the ingestion of the bolus.

With the same method used in this investigation, it has been shown that women have less ingestion flow and volume in each swallow than men ${ }^{(2)}$, results confirmed by this study. Swallowing evaluation by videofluoroscopy found slower pharyngeal passage of a swallowed bolus in women compared to men ${ }^{(11)}$. The observed differences in swallowing between men and women may be due to anatomical differences between genders ${ }^{(16)}$. Men and women had the same response to the ingestion of acidic liquid, i.e., decreased ingestion flow and volume in each swallow.

There are some limitations in this investigation. The num- ber of patients included might be higher and evaluation of the oral, pharyngeal and esophageal transit was not performed. Performing the same evaluation in patients without treatment for GERD and symptomatic may reach different results.

\section{CONCLUSIONS}

Liquid acidic bolus has ingestion dynamics different than a neutral liquid. There was no difference between the liquid ingestion of patients with gastroesophageal reflux disease and healthy subjects. Women have lower flux of ingestion and lower volume in each swallow than men, with acidic and neutral boluses.

Gomes DC, Dantas RO. Ingestão de líquidos ácido e neutro em pacientes com doença do refluxo gastroesofágico. Arq Gastroenterol. 2014,51(3):217-20. RESUMO - Contexto - Líquido ácido tem um trânsito pelo esôfago distal mais lento do que líquido neutro. Nossa hipótese é que um bolo azedo ácido tem uma ingestão com diferente dinâmica em relação à ingestão de um bolo neutro. Método - Foram avaliadas a dinâmica da ingestão de 100 mL de líquido ácido azedo (suco de limão concentrado, pH: 3,0) e $100 \mathrm{~mL}$ de água (pH: 6,8) em 50 indivíduos saudáveis e 29 pacientes com doença do refluxo gastroesofágico (DRGE). Foi medido o tempo para ingerir o volume total, o número de deglutições ao ingerir o volume, o intervalo entre as deglutições, o fluxo de ingestão e o volume ingerido em cada deglutição. Resultados - Em ambos os grupos o líquido ácido levou mais tempo para ser ingerido, com um maior número de deglutições, fluxo mais lento de ingestão e um menor volume em cada deglutição. Não houve diferença entre indivíduos saudáveis e pacientes com DRGE. A ingestão em mulheres foi mais longa do que nos homens. Conclusão - Líquido ácido tem uma dinâmica de ingestão diferente do líquido neutro, que pode ser consequência do trânsito mais lento através do corpo esofágico distal ou antecipação à ingestão de liquido azedo. Pacientes com DRGE tiveram a mesma ingestão prolongada do líquido ácido que os indivíduos saudáveis.

DESCRITORES - Refluxo gastroesofágico. Transtornos de deglutição. Acidez.

\section{REFERENCES}

1. Alves LMT, Cassiani RA, Santos CM, Dantas RO. Avaliação da deglutição pelo teste de ingestão de água. GED. 2007;26:1-4.

2. Alves LMT, Cassiani RA, Santos CM, Dantas RO. Gender effect on the clinical measurement of swallowing. Arq Gastroenterol. 2007;44:227-9.

3. Alves LMT, Fabio SRC, Dantas RO. Effect of bolus taste on the esophageal transit of patients with stroke. Dis Esophagus. 2012;26:305-10.

4. Alves LMT, Secaf M, Dantas RO. Oral, pharyngeal, and esophageal transit of an acidic bolus in healthy subjects. Esophagus. 2013;10:217-22.

5. Alves LMT, Secaf M, Dantas RO. Effect of a bitter bolus on oral, pharyngeal and esophageal transit of healthy subjects. Arq Gastroenterol. 2013;50;31-4.

6. Bredenoord AJ, Weustein BL, Smout AJ. Symptom association analysis in ambulatory gastro-oesophageal reflux monitoring. Gut. 2005;54:1810-17.

7. Bredenoord AJ, Pandolfino JE, Smout AJPM. Gastro-oesophageal reflux disese Lancet. 2013;381:1933-42.

8. Cassiani RA. Estudo da deglutição em pacientes com a doença do refluxo gastroesofágico. Doctoral Thesis. Faculdade de Medicina de Ribeirão Preto da Universidade de São Paulo, 2010.

9. Chee C, Arshad S, Sing S, Mistry S, Handy S. The influence of chemical gustatory stimuli and oral anaesthesia on healthy human paryngeal swallowing. Chem Senses. 2005:30:393-400

10. Chen CL, Yi CH, Cook IJ. Differences in oesophageal bolus transit between patients with and without erosive reflux disease. Dig Liver Dis. 2008;40:348-54.

11. Dantas RO, Cassiani, RA, Santos CM, Gonzaga GC, Alves LMT, Mazin SC Effect of gender on swallow event duration assessed by videofluoroscopy. Dysphagia. 2009;24:280-4.
12. Frazzoni M, Manta R, Mirante VG, Conigliaro R, Frazzoni L Melotti G. Esophageal chemical clearance is impaired in gastro-esophgeal reflux disease - a $24 \mathrm{~h}$ impedance-pH monitoring assessment. Neurogastroenterol Motil. 2013;25:399e295.

13. Hamdy S, Jilani S, Price V, Parker C, Hall N, Power M. Modulation of human swallowing behaviour by thermal and chemical stimulation in health and after brain injury. Neurogastroenterol Motil. 2003:15:69-77.

14. Hughes TAT, Wiles CM. Clinical measurement of swallowing in health and in neurogenic dysphagia. Q J Med. 1996;89:109-16.

15. Kidambi T, Toto E, Ho N, Taft T, Hirano I. Temporal trends in the relative prevalence of dysphagia in reflux esophagitis. World J Gastroenterol. 2012;18:4335-41.

16. Nascimento WV, Cassiani RA, Dantas RO. Gender effect on oral volume capacity. Dysphagia. 2012;27:384-9.

17. Palmer PM, Mculloch TM, Jaffe D, Neel AT. Effect of a sour bolus on the intramuscular electromyography (EMG) activity of muscles in the submental region. Dysphagia. 2005;20:210-7.

18. Richter J. The many manifestations of gastroesophageal reflux disease: presentation, evaluation and treatment. Gastroenterol Clin N Am. 2007;36:577-99.

19. Santos CM, Cassiani RA, Dantas RO. Videofluoroscopic evaluation of swallowing in Chagas' disease. Dysphagia. 2011;26:361-5.

20. Shall R. Estimation in generalized linear models with random effects. Biometrika. 1991;78:719-27.

21. Simrém M, Silny J, Holloway R, Tack J, Janssens J, Sifrim D. Relevance of ineffective oesphageal motility during oesophageal acid clearance. Gut. 2003;53:784-90.

22. Triadafilopoulos G, Hallstone A, Nelson-Abott H, Bedinger K. Oropharyngeal and esophageal interrelationships in patients with nonobstructive dysphagia. Dig Dis Sci. 1992;37:551-7. 